\title{
Seasonal dynamics of a drosophilid (Diptera) assemblage and its potencial as bioindicator in open environments
}

\author{
Luís Bizzo ${ }^{1}$, Marco S. Gottschalk², Daniela C. De Toni ${ }^{3}$ \& Paulo R. P. Hofmann ${ }^{3}$
}

1. Programa de Pós-Graduação em Entomologia, Faculdade de Filosofia, Ciências e Letras de Ribeirão Preto, Universidade de São Paulo, Avenida Bandeirantes, 3900, Bloco 2, 14049-900 Ribeirão Preto, SP, Brazil. (luisbizzo@usp.br)

2. Laboratório de Entomologia, Instituto de Ciências Biológicas, Universidade Federal do Rio Grande, Campus Carreiros, Avenida Itália, km 08, Prédio 06, 96201-900 Rio Grande, RS, Brazil. (gotts007@yahoo.com)

3. Laboratório de Drosofilídeos, Departamento de Biologia Celular, Embriologia e Genética, Centro de Ciências Biológicas, Campus Universitário, Universidade Federal de Santa Catarina, 88036-400 Florianópolis, SC, Brazil. (ddetoni@ccb.ufsc.br; prph@ccb.ufsc.br)

\begin{abstract}
Drosophila Fallen, 1823 (Diptera, Drosophilidae) is for long a well-established model organism for genetics and evolutionary research. The ecology of these flies, however, has only recently been better studied. Recent papers show that Drosophila assemblies can be used as bioindicators of forested environment degradation. In this work the bioindicator potential of drosophilids was evaluated in a naturally opened environment, a coastal strand-forest (restinga). Data from nine consecutive seasonal collections revealed strong temporal fluctuation pattern of the majority of Drosophila species groups. Drosophila willistoni group was more abundant at autumns, whereas $D$. cardini and D. tripunctata groups were, respectively, expressive at winters and springs, and D. repleta group at both seasons. The exotic species D. simulans Sturtevant, 1919 (from D. melanogaster group) and Zaprionus indianus Gupta, 1970 were most abundant at summers. Overall, the assemblage structure did not show the same characteristics of forested or urban environments, but was similar to the forests at winters and to cities at summers. This raises the question that this locality may already been under urbanization impact. Also, this can be interpreted as an easily invaded site for exotic species, what might lead to biotic homogenization and therefore can put in check the usage of drosophilid assemblages as bioindicators at open environments.
\end{abstract}

KEYWORDS. Drosophila, seasonality, bioindicators, restinga, Brazil.

RESUMO. Dinâmica sazonal de uma assembléia de drosofilídeos (Diptera) e seu potencial como bioindicadora em ambientes abertos. Drosophila Fallen, 1823 (Diptera, Drosophilidae) é, há muito tempo, um organismo modelo em pesquisas de genética e evolução. A ecologia destas moscas, no entanto, apenas recentemente foi melhor estudada. Trabalhos recentes apontam que as assembléias de Drosophila podem ser utilizadas como bioindicadoras de degradação de ambientes florestais. Neste trabalho, foi avaliado o potencial bioindicador dos drosofilídeos em um ambiente de restinga, naturalmente aberto. Dados de nove coletas sazonais consecutivas revelaram um forte padrão de flutuação temporal na maioria dos grupos de espécies de Drosophila. O grupo D. willistoni foi mais abundante nos outonos, enquanto os grupos $D$. cardini e D. tripunctata foram, respectivamente, expressivos nos invernos e primaveras, e o grupo D. repleta em ambas as estações. As espécies exóticas D. simulans Sturtevant, 1919 (do grupo D. melanogaster) e Zaprionus indianus Gupta, 1970 foram mais abundantes nos verões. Em geral, a estrutura desta assembléia não mostrou as mesmas características de ambientes florestais ou urbanos, mas mostrou-se similar às florestas nos invernos e aos urbanizados nos verões. Isto demonstra que esta localidade já pode estar sofrendo impacto da urbanização. Também, este pode ser interpretado como um local facilmente invadido por espécies exóticas, o que pode levar à homogeneização biótica e, portanto, pode por em cheque o uso de assembléias de drosofilídeos como bioindicadores em ambientes abertos.

PALAVRAS-CHAVE. Drosophila, sazonalidade, bioindicadores, restinga, Brasil.

Drosophila Fallen, 1823 (Diptera, Drosophilidae) is for long a model organism in genetics and evolution. Community ecology studies with these flies are still scarce, but provided significant improvements in the area of species competition (review in HARTLEY \& SHORROCKS, 2002). The richness of this genus, though, is still poorly known, especially in the Neotropical region, where Medeiros \& Klazcko (2004) and Döge et al. (2008) estimated that nearly $40 \%$ of the brazilian Drosophila species are still undescribed. Even the geographical distribution of many species is still not well established (DöGE et al., 2006, 2007; MATA et al., 2008a).

The American invasion of the African drosophilid Zaprionus indianus Gupta, 1970 instigated studies of its impact on the assemblies' structure and on the temporal dynamics of native species. Collections were performed at many ecosystems, like the Atlantic Rain Forest (MATEus et al., 2006; Torres \& Madi-RavazZi, 2006; DE Toni et al., 2007), mangroves (Schmiтz et al., 2007), cerrado lato sensu (the Brazilian savanna) (Tidon et al., 2003; Tidon, 2006; MATA et al., 2008b), and even urban environments (GoÑ et al., 1997; FerReira \& TidON, 2005; Silva et al., 2005b; GOTTSCHALK et al., 2007). These and other studies also demonstrated the possible use of drosophilids as bioindicators of forest degradation (PARSONS, 1991; Martins, 2001; Avondet et al., 2003; FerReira \& Tidon, 2005; Silva et al., 2005b).

Among the Brazilian coastal ecosystems, mangroves and restingas (strand forest) are the most extensive. The restingas are distributed along almost $80 \%$ of the Brazilian shore and comprises an herbaceous to arboreal vegetational complex, usually not very dense, that is situated between the beach sand dunes and other ecosystems, like the Atlantic Rain Forest stricto sensu. Schmitz et al. (2007) made extensive collections on mangroves at Florianópolis (state of Santa Catarina, southern Brazil) and found somewhat different assemblies' structure when compared to urban and forested ecosystems of the same city (GOTTSCHALK et al., 2007). Bizzo \& Sene (1982) made the sole survey of drosophilids at a restinga site and found a similar structure to the Atlantic Rain Forest nearby. 
As MATA et al. (2008b) pointed out, species richness and precedence (i.e. exotic or naturally endemic), as well as assemblage structure across habitats offer a good picture of the assemblage disturbance. Thus, the present work aims to analyze the temporal dynamics of a drosophilid assemblage in a coastal ecosystem, discussing the usage of these flies as bioindicators in open environments.

\section{MATERIAL AND METHODS}

Collections were performed in a well preserved arboreal strand forest (restinga) fragment in a shrub to grassland strand forest matrix at Praia da Joaquina, Florianópolis $\left(27^{\circ} 38^{\prime} 21^{\prime \prime} \mathrm{S}\right.$; $48^{\circ} 27^{\prime}$ '49' W), state of Santa Catarina, southern Brazil. The site is $350 \mathrm{~m}$ far from a low density residential area and, in the same direction, $650 \mathrm{~m}$ far from a chain of mountains called Morro da Lagoa da Conceição. In this region, the climate is classified as Cfa by KöPPEN (1948), that is, subtropical with the coldest month average temperature inferior to $18^{\circ} \mathrm{C}$ and superior to $22^{\circ} \mathrm{C}$ in the hottest month. Rain is concentrated in summer but there is no defined dry season.

Between May 2002 (autumn) and May 2004, nine consecutive collections were performed, one per season. In each collection, 50 banana-baited traps (TIDON \& SENE, 1988) were hung to trees at $1.5 \mathrm{~m}$ high and left in field for four days. Traps were distributed two to four meters far from each other, covering an area of about $200 \mathrm{~m}^{2}$.

Captured flies were identified to species level utilizing keys, descriptions and male terminalia dissection, which followed WHEELER \& KaMBYSELlis' (1966) technique, modified by KANESHIRo (1969). Only individuals identified to species or sub-group were used in further analysis. Voucher specimens are deposited at Laboratório de Drosofilídeos, Universidade Federal de Santa Catarina.

The analyzed parameters were: number of individuals $(\mathrm{N})$ and species collected $(\mathrm{S})$, and its relative abundance $\left(p_{i}=\right.$ number of individuals of species $i$ / total number of individual per collection). Were also calculated the diversity index of Simpson in its inverse form, $l=1 / \mathrm{D}$, where $\mathrm{D}=\Sigma\left[n_{i} .\left(n_{i}-1\right)\right] /[\mathrm{N} .(\mathrm{N}-1)]$ and $n_{i}$ is the number of individuals from species $i$ in the collection, and the Shannon-Wiener index, $\mathrm{H}^{\prime}=-\Sigma\left[p_{i} \cdot \ln \left(p_{i}\right)\right]-[(\mathrm{S}-1) / 2 . \mathrm{N}]$ (KREBS, 1999). While the Simpson index is more influenced by dominance, the Shannon-Wiener index is more biased towards species richness (MAGURRAN, 2003). We opted to use both because they have good performance and are widely used in the ecological literature, what permits future comparisons.

The sample effort and richness of the collections were estimated through rarefaction $\left(S_{\text {RAR }}\right)$ (KREBS, 1999), what makes possible to compare samples with very different $\mathrm{N}$.

Similarity between collections was estimated using Morisita similarity index, with clustering through UPGMA algorithm (KREBS, 1999). All analyses were performed in program PAST 1.56 (HAMMER et al., 2001).

\section{RESULTS}

A total of 11,787 individuals of 49 Drosophilidae species from seven genera were collected (Tab. I). Besides Drosophila, Zaprionus Coquillett, 1901 was the only genus widely collected. Five Drosophila species, one Amiota Loew, 1862 and one Mycodrosophila Oldenberg, 1914 could not be identified and summed up to 427 individuals (less than $4 \%$ of the total sample). Nine species are exotic or cosmopolitan (identified with double asterisks on table I), and corresponded to $38 \%$ of the specimens collected.

All surveyed parameters presented great oscillation (Tab. II) and almost always in a clear pattern. Number of individuals was much higher in summers and autumns. Winters and the spring of 2003 (Spr2003), however, were proportionally richer and more diverse, as showed by $\mathrm{S}_{\mathrm{RAR}}$ and the diversity indexes. Although there is much overlapping among standard deviations in rarefaction analysis, summer samples are clearly poorer (Fig. 1).

Community structure at autumns and springs were also very characteristic: the first joined a separate cluster and the latter were extremely similar (Fig. 2); summer and winter collections, on the other hand, were less related. These similarities in richness and community structure are a byproduct of drosophilid population dynamics, and here species groups' dynamics represents much of the assemblage variation.

Almost all species groups of Drosophila as well as Z. indianus presented evident seasonal patterns (Fig. 3). Drosophila willistoni group was dominant at autumns; D. melanogaster group was always very common but

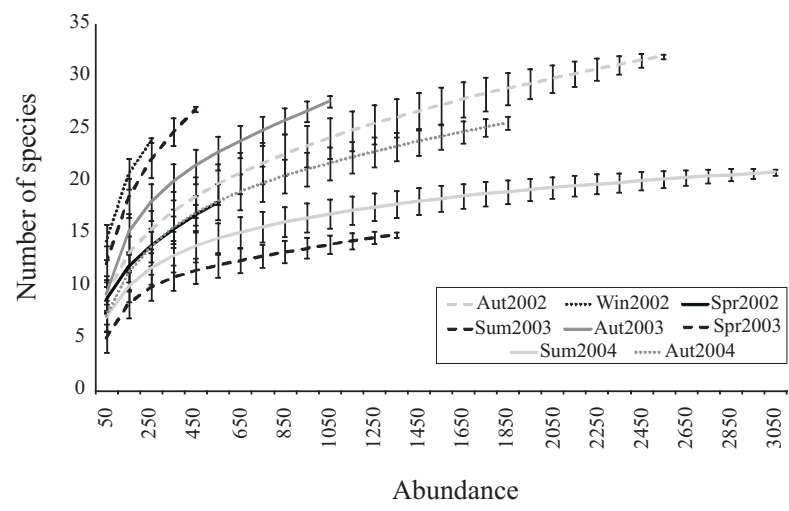

Figure 1. Rarefaction curves of the seasonal collections. Vertical bars indicate standard errors (Aut, autumn; Spr, spring; Sum, summer; Win, winter).

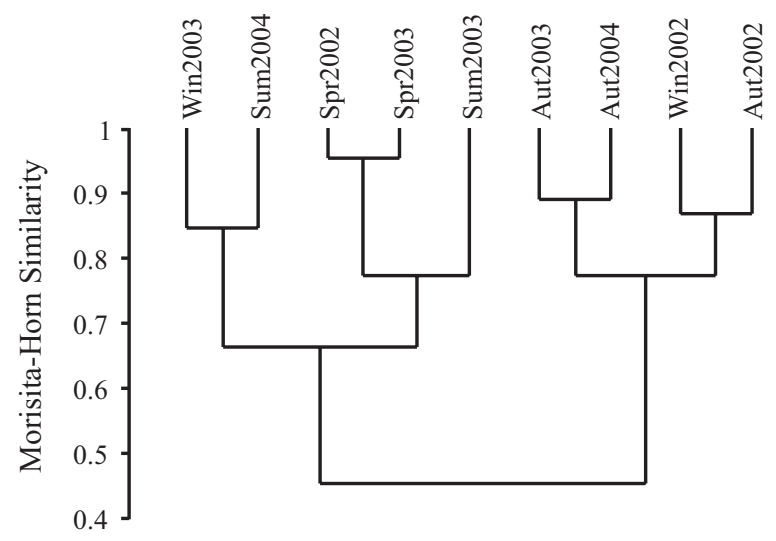

Figure 2. Morisita similarity index dendrogram, with clustering though UPGMA (Aut, autumn; Spr, spring; Sum, summer; Win, winter). 
Table I. Drosophilid species identified and their abundances in each seasonal collection ( $n i$, is the absolute abundance of the species on the sample; pi, its respective relative abundance; asterisks represents pi<0,01). Exotic species are marked with double asterisks (Aut, autumn; Spr, spring; Sum, summer; Win, winter).

\begin{tabular}{|c|c|c|c|c|c|c|c|c|c|c|c|}
\hline $\begin{array}{l}\text { Genera/ Subgenera/ } \\
\text { species group }\end{array}$ & Species & $\begin{array}{c}\text { Aut } \\
2002\end{array}$ & $\begin{array}{l}\text { Win } \\
2002\end{array}$ & $\begin{array}{c}\text { Spr } \\
2002\end{array}$ & $\begin{array}{l}\text { Sum } \\
2003\end{array}$ & $\begin{array}{c}\text { Aut } \\
2003\end{array}$ & $\begin{array}{c}\text { Win } \\
2003\end{array}$ & $\begin{array}{c}\text { Spr } \\
2003\end{array}$ & $\begin{array}{l}\text { Sum } \\
2004\end{array}$ & $\begin{array}{c}\text { Aut } \\
2004\end{array}$ & $n i(p i)$ \\
\hline \multicolumn{12}{|l|}{ Genus Drosophila } \\
\hline \multicolumn{12}{|l|}{ Subgenus Dorsilopha } \\
\hline D. busckii group & $\begin{array}{l}\text { D. busckii } \\
\text { Coquillett, } 1901^{* *}\end{array}$ & 0 & 1 & 0 & 0 & 0 & 0 & 0 & 0 & 1 & $2(*)$ \\
\hline \multicolumn{12}{|l|}{ Subgenus Drosophila } \\
\hline \multirow[t]{3}{*}{ D. annulimana group } & $\begin{array}{l}\text { D. annulimana } \\
\text { Duda, } 1927\end{array}$ & 0 & 2 & 1 & 0 & 1 & 0 & 4 & 1 & 0 & $9(*)$ \\
\hline & D. ararama & 0 & 0 & 0 & 0 & 0 & 0 & 0 & 1 & 0 & $1(*)$ \\
\hline & $\begin{array}{l}\text { Pavan \& Cunha, } 1947 \\
\text { D. schineri }\end{array}$ & 1 & 0 & 1 & 0 & 1 & 0 & 1 & 0 & 0 & $4(*)$ \\
\hline D. bromeliae group & $\begin{array}{l}\text { Pereira \& Vilela, } 1987 \\
\text { D. bromelioides }\end{array}$ & 8 & 0 & 0 & 0 & 13 & 0 & 0 & 30 & 0 & $51(*)$ \\
\hline & Pavan \& Cunha, 1947 & & & & & & & & & & \\
\hline \multirow[t]{5}{*}{ D. calloptera group } & $\begin{array}{l}\text { D. atrata } \\
\text { Burla \& Pavan. } 1953\end{array}$ & 0 & 0 & 0 & 0 & 0 & 0 & 0 & 1 & 0 & $1(*)$ \\
\hline & $\begin{array}{l}\text { D. calloptera } \\
\text { Schiner } 1868\end{array}$ & 3 & 0 & 0 & 0 & 0 & 0 & 0 & 0 & 0 & $3(*)$ \\
\hline & $\begin{array}{l}\text { D. quadrum } \\
\text { (Weidemann, 1830) }\end{array}$ & 0 & 0 & 0 & 0 & 1 & 0 & 0 & 0 & 0 & $1(*)$ \\
\hline & D. schildi & 0 & 0 & 0 & 0 & 1 & 0 & 0 & 0 & 0 & $1(*)$ \\
\hline & $\begin{array}{l}\text { Malloch, } 1924 \\
\text { unidentified }\end{array}$ & 0 & 0 & 0 & 0 & 1 & 0 & 0 & 0 & 0 & $1(*)$ \\
\hline D. caponei group & $\begin{array}{l}\text { D. caponei } \\
\text { Pavan \& Cunha, } 1947\end{array}$ & 0 & 0 & 6 & 1 & 18 & 0 & 0 & 14 & 5 & $44(*)$ \\
\hline \multirow[t]{5}{*}{ D. cardini group } & $\begin{array}{l}\text { D. cardini } \\
\text { Sturtevant, } 1916\end{array}$ & 2 & 0 & 0 & 3 & 0 & 0 & 0 & 0 & 0 & $5(*)$ \\
\hline & D. cardinoides & 45 & 1 & 0 & 1 & 5 & 0 & 1 & 0 & 1 & $54(*)$ \\
\hline & Dobzhansky \& Pavan, 1943 & & & & & & & & & & \\
\hline & D. neocardini & 3 & 0 & 16 & 0 & 0 & 0 & 8 & 5 & 1 & $33(*)$ \\
\hline & $\begin{array}{l}\text { Streisinger, } 1946 \\
\text { D. polymorpha } \\
\text { Dobzhansky \& Pavan, } 1943\end{array}$ & 67 & 9 & 40 & 18 & 17 & 4 & 25 & 63 & 11 & $\begin{array}{r}254 \\
(0.02)\end{array}$ \\
\hline \multirow[t]{4}{*}{ D. guarani group } & D. ornatifrons Duda, 1927 & 5 & 1 & 0 & 0 & 0 & 0 & 2 & 0 & 0 & $8(*)$ \\
\hline & $\begin{array}{l}\text { D. griseolineata } \\
\text { Duda, } 1927\end{array}$ & 10 & 1 & 1 & 0 & 3 & 1 & 1 & 3 & 2 & $22(*)$ \\
\hline & $\begin{array}{l}\text { D. maculifrons } \\
\text { Duda, } 1927\end{array}$ & 0 & 0 & 0 & 0 & 0 & 0 & 0 & 0 & 1 & $1(*)$ \\
\hline & unidentified & 0 & 2 & 3 & 0 & 0 & 0 & 0 & 5 & 6 & $16(*)$ \\
\hline D. immigrans group & $\begin{array}{l}\text { D. immigrans } \\
\text { Sturtevant, } 1921 * *\end{array}$ & 0 & 0 & 0 & 0 & 0 & 2 & 0 & 0 & 0 & $2(*)$ \\
\hline D. pallidipennis group & $\begin{array}{l}\text { D. pallidipennis } \\
\text { Dobzhansky \& Pavan, } 1943\end{array}$ & 0 & 3 & 0 & 2 & 4 & 1 & 0 & 3 & 1 & $14(*)$ \\
\hline \multirow[t]{9}{*}{ D. repleta group } & $\begin{array}{l}\text { D. fascioloides } \\
\text { Dobzhansky \& Pavan, } 1943\end{array}$ & 0 & 2 & 0 & 0 & 0 & 0 & 0 & 0 & 0 & $2(*)$ \\
\hline & D. onca & 1 & 3 & 0 & 0 & 0 & 0 & 2 & 0 & 0 & $6(*)$ \\
\hline & $\begin{array}{l}\text { Dobzhansky \& Pavan, } 1943 \\
\text { D. hydei }\end{array}$ & 0 & 0 & 0 & 1 & 0 & 0 & 1 & 0 & 0 & $2(*)$ \\
\hline & Sturtevant, 1921 & & & & & & & & & & \\
\hline & D. mercatorum & 14 & 4 & 51 & 14 & 20 & 10 & 68 & 14 & 8 & 203 \\
\hline & Patterson \& Wheeler, 1942 & & & & & & & & & & $(0.02)$ \\
\hline & $\begin{array}{l}\text { D. serido } \\
\text { Vilela \& Sene, } 1977\end{array}$ & 1 & 0 & 0 & 0 & 0 & 0 & 0 & 0 & 0 & $1(*)$ \\
\hline & D. zottii Vilela, 1983 & 0 & 4 & 0 & 0 & 0 & 4 & 0 & 0 & 0 & $8(*)$ \\
\hline & unidentified & 5 & 13 & 0 & 10 & 7 & 1 & 0 & 8 & 3 & $47(*)$ \\
\hline \multirow[t]{5}{*}{ D. tripunctata group } & $\begin{array}{l}\text { D. cuaso Bächli, } \\
\text { Vilela \& Ratcov, } 2000\end{array}$ & 0 & 0 & 0 & 0 & 0 & 0 & 0 & 0 & 7 & $7(*)$ \\
\hline & $\begin{array}{l}\text { D. mediopunctata } \\
\text { Dobzhansky \& Pavan, } 1943\end{array}$ & 5 & 12 & 1 & 0 & 5 & 5 & 7 & 0 & 0 & $35(*)$ \\
\hline & $\begin{array}{l}\text { D. paraguayensis } \\
\text { Duda, } 1927\end{array}$ & 12 & 14 & 2 & 0 & 10 & 2 & 3 & 1 & 7 & $51\left(^{*}\right)$ \\
\hline & $\begin{array}{l}\text { D. roehrae } \\
\text { Pipkin \& Heed, } 1964\end{array}$ & 1 & 1 & 1 & 0 & 7 & 0 & 0 & 2 & 0 & $12\left(^{*}\right)$ \\
\hline & $\begin{array}{l}\text { D. bandeirantorum } \\
\text { Dobzhansky \& Pavan, } 1943\end{array}$ & 2 & 0 & 0 & 0 & 0 & 2 & 1 & 0 & 0 & $5(*)$ \\
\hline
\end{tabular}


Table I (cont.)

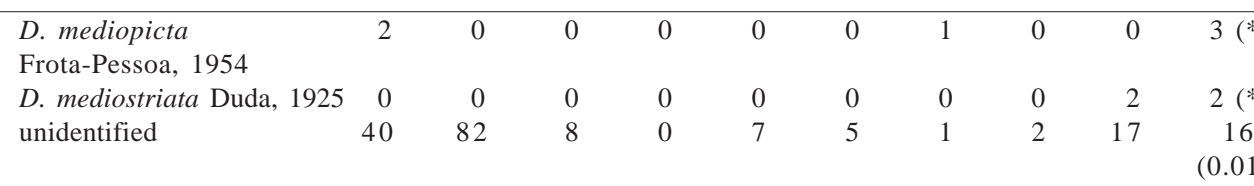

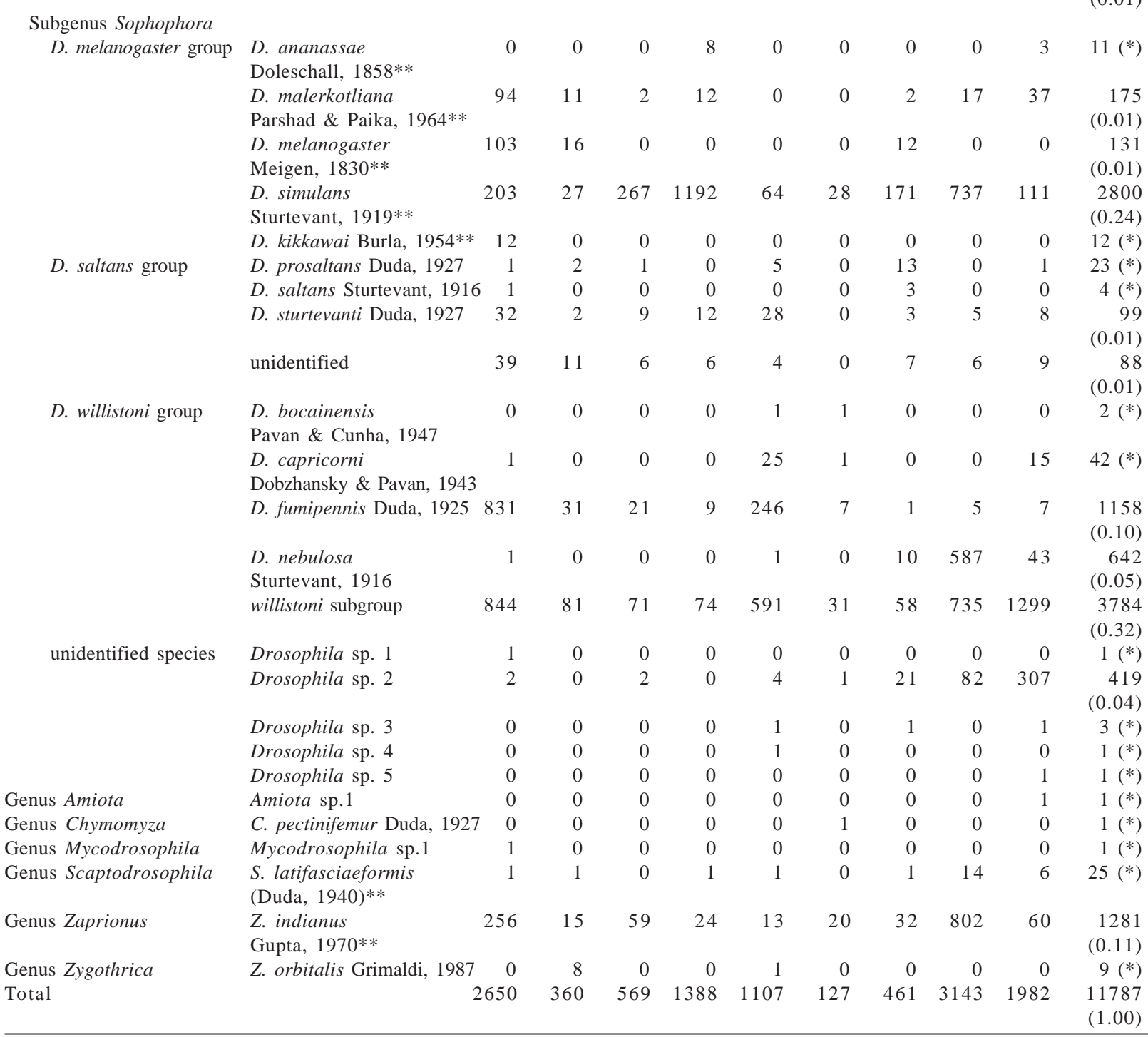

Table II. For each seasonal collection is given the number of species $(\mathrm{S})$ and individuals $(\mathrm{N})$ collected, rarefied $\mathrm{S}$ for $\mathrm{N}=121\left(\mathrm{~S}_{\mathrm{RAR}}\right)$, and the diversity indices of Shannon-Wiener $\left(\mathrm{H}^{\prime}\right)$ and Simpson $(l)$ (Aut, autumn; Spr, spring; Sum, summer; Win, winter).

\begin{tabular}{lcrccc}
\hline & $\mathrm{S}$ & $\mathrm{N}$ & $\mathrm{S}_{\mathrm{RAR}}$ & \multicolumn{1}{c}{$\mathrm{H}^{\prime}$} & $l$ \\
\hline Aut2002 & 32 & 2650 & 12.24 & 1.84 & 4.28 \\
Win2002 & 24 & 360 & 19.38 & 2.40 & 6.75 \\
Spr2002 & 18 & 569 & 11.13 & 1.74 & 3.59 \\
Sum2003 & 15 & 1388 & 7.63 & 0.65 & 1.32 \\
Aut2003 & 28 & 1107 & 13.90 & 1.59 & 2.83 \\
Win2003 & 18 & 127 & 18 & 2.15 & 6.28 \\
Spr2003 & 27 & 461 & 17.05 & 2.16 & 5.14 \\
Sum2004 & 21 & 3143 & 9.34 & 1.72 & 4.68 \\
Aut2004 & 26 & 1982 & 10.36 & 1.26 & 2.11 \\
Sample & 49 & 11787 & & 2.07 & 5.08 \\
\hline
\end{tabular}

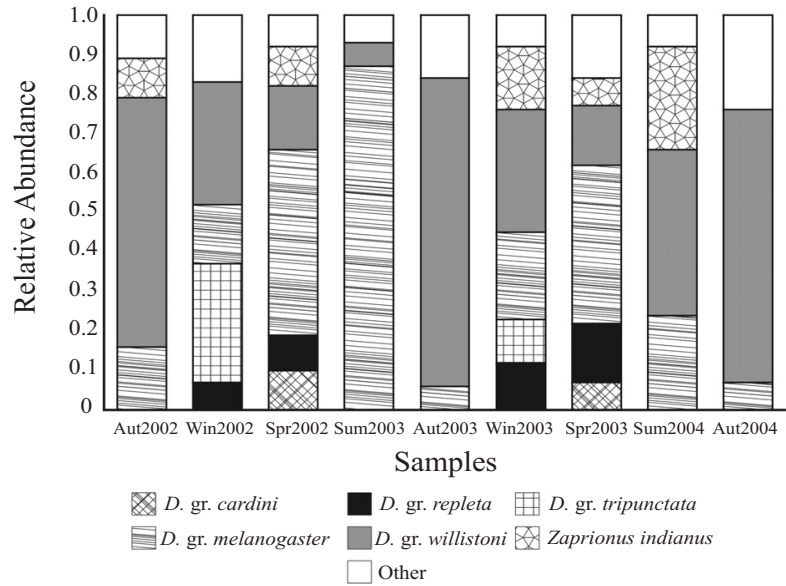

Figure 3. Relative abundance of the main representative Drosophila groups and Zaprionus indianus Gupta, 1970 in each seasonal collection (Aut, autumn; Spr, spring; Sum, summer; Win, winter). 
was less represented in autumns and winters, increasing at springs and particularly dominant at summer of 2003 (Sum2003). The D. tripunctata group was more represented at winters and less at summers (Tab. I); the same happened to the $D$. cardini group at springs and winters, respectively. In these last two seasons, the $D$. repleta group increased its abundance, and $Z$. indianus was more abundant at summer of 2004 (Sum2004).

\section{DISCUSSION}

All exotic species of Drosophilidae registered in Brazil were collected at this site (GOTTSCHALK et al., 2007), and were usually more abundant in hot seasons. Bizzo \& SENE (1982) found less exotic species but a similar seasonality, an observation that, together with data from breeding sites, might corroborate the observations that $Z$. indianus is not excluding other species through competition (LEÃo \& TidON, 2004; Silva et al., 2005a; VALIATI et al., 2005).

As a general rule, the analyzed parameters presented a clear seasonal pattern, in agreement with other studies. The small $\mathrm{N}$ in winters, the coldest and driest period, was registered on other Brazilian localities too, together with the higher species diversity in this season (SAAVEdRA et al., 1995; TIDON, 2006; DE TONI et al., 2007), irrespectively of N. Thus, this seems to be a common feature of drosophilid assemblies.

In the rarefaction analysis, however, the species richness of winters seems to be super estimated, a bias of small samples. Nevertheless, the technique was robust in detecting the lower richness of summers.

Among the native species groups, the increased presence of the $D$. tripunctata group in winters is well documented, as well as from the $D$. willistoni group in autumns and summers (DOBZHANSKY \& PAVAN, 1950; FRANK \& VALENTE, 1985).

Only the $D$. melanogaster group showed an unexpected seasonal dynamics, being more abundant in springs and in the first summer. Other works report autumns or summers as seasons of increased N (FRANCK \& VAlente, 1985; BenAdo \& BRncic, 1994; Tidon, 2006; Schmitz et al., 2007). Zaprionus indianus was more abundant in the summer, the hottest and wettest period, what corroborates several previous studies (CASTRO \& VAlente, 2001; Tidon et al., 2003; Silva et al., 2005b; DE Toni et al., 2007).

In the majority of papers that dealt with drosophilid seasonality, only one or two taxa present a temporal pattern, while others differed between years (e.g. BonORINO \& Valente, 1989; CAstro \& VAlente, 2001; Silva et al., 2005a). The lack of patterns is expected, because changes in the environmental conditions and resource availability are common between years and can modify the structure of drosophilid assemblages (DoBZHANSKY \& PAVAN, 1950; PIPKIN, 1953), what is ultimately part of the evolutionary process (TidON-SKLORZ \& SENE, 1992). The diversity of resources and the consequently ecological complexity that results certainly contributes to the unpredictability of species fluctuation.

Here, surprisingly, the majority of taxa presented a clear seasonal dynamics. This could be expected to be found within mature assemblies in stable environments (WORM \& DuFFY, 2003), but it is difficult to explain this pattern in this assemblage, with different dominant species between seasons and in this harsh and unpredictable ecosystem.

The coastal strand forest vegetation has less species diversity than its native surroundings (the Atlantic Rain Forest sensu strictu) and is subject to higher insolation, winds, drought and daily temperature amplitude. This contributes to the determination of resources' availability time, besides the own capacity of the flies to survive and persist at this oscillating environment. Overall, these complex interactions seem to be modeling the assemblage structure, which changes abruptly within seasons.

When compared to other environments, the restinga assemblage did not present a characteristic structure, as the ones of forested or urban sites. At the Atlantic Rain Forest, the $D$. willistoni subgroup and $D$. saltans group are usually dominant and there are dozens of rare native species (PAVAN, 1959; MEDEIROS \& KLACZKO, 2004; De Toni et al., 2007). The urban sites, on the other hand, are strongly dominated by exotic species, usually D. simulans Sturtevant, 1919 or D. malerkotliana Parshad \& Paika, 1964 (D. melanogaster group) (BONORINO \& VALENTE, 1989; GoÑ et al., 1997) and, more recently, by Z. indianus (FERREIRA \& Tidon, 2005; Silva et al., 2005b; GotTschalk et al., 2007).

At summers, less species were collected and $D$. simulans and Z. indianus were dominant, what resembles this structure to an urban environment. This suggests that, although not closer to the city then other studied forest sites (De Toni \& Hofmann, 1995; De Toni et al., 2007; GotTschalк et al., 2007), this restinga fragment is already under human impact.

In contrast, autumns' assemblage structures were more similar to the forest ones, with higher $\mathrm{S}$, dominance of the D. willistoni group and presence of characteristic native groups, such as tripunctata. The small representativeness from $D$. saltans group can be related to the low humidity of the site, since they seem to prefer humid places (Jonas S. Döge, pers. comm.).

In sum, because of not possessing a characteristic drosophilid assemblage structure and being an opened environment, the strand forest is apparently more suitable for the invasion of exotic species; there may be even seasonal invasions. In fact, biotic homogenization is a major impact of urbanization (McKINNEY, 2006; RoONEY et al., 2007) and has been seen in other insect assemblages, including Drosophila (e.g. FERREIRA \& Tidon, 2005; GotTschalK et al., 2007).

Although in this particular case the assemblage might not be a good bioindicator of environment degradation, the use of Drosophila is still a growing field. There have been propositions of indicator species by SAAVEDRA et al. (1995), MARTINS (2001), FERREIRA \& Tidon (2005) and Mata et al. (2008b) but few examined the assemblage as a whole.

Our observation also raises questions about the ecological processes that protect forests from invasions of exotic species. Thus, future studies that show how populations interact and maintain in natural ecosystems are extremely important to untangle the assemblies' dynamics and the possible use of this knowledge in the management and conservation of areas of ecological interest. 
Acknowledgments. We are indebted to Dr. Hermes J. Schmitz, Msc. Jonas S. Döge, Msc. Sabrina C. F. Oliveira and Hugo B. Mozerle for assistance in field collections and fly identification, and to PET/SESu and CNPq for financial support. Jonas S. Döge and Dr. Tânia T. Castellani kindly read an early version of the manuscript. Dr. Vera L. S. Valente and an anonymous reviewer made important suggestions and improvements, for which we are also grateful.

\section{REFERENCES}

Avondet, J. L.; Blair, R. B.; Berg, D. J. \& Ebbert, M. A. 2003. Drosophila (Diptera: Drosophilidae) response to changes in ecological parameters across an urban gradient. Environmental Entomology 32(2):347-358.

Benado, M. \& Brncic, D. 1994. An eight year phenological study of a local drosophilid community in central Chile. Journal of Zoological Systematics and Evolutionary Research 32:51-63

Bizzo, N. M. V. \& Sene, F. M. 1982. Studies on the natural populations of Drosophila from Peruíbe (SP), Brazil (Diptera; Drosophilidae). Revista Brasileira de Biologia 42(3):539544.

Bonorino, C. B. C. \& Valente, V. L. S. 1989. Studies on wild and urban populations and breeding sites of Drosophila nebulosa. Revista Brasileira de Biologia 49(3):771-776.

Castro, F. L. \& Valente, V. L. S. 2001. Zaprionus indianus is invading drosophilid communities in the southern brazilian city of Porto Alegre. Drosophila Information Service 84:15-17

De Toni, D. C.; Gottschalk, M. S.; Cordeiro, J.; Hofmann, P. P. R. \& Valente, V. L. S. 2007. Study of the Drosophilidae (Diptera) communities on atlantic forest islands of Santa Catarina state, Brazil. Neotropical Entomology 36(3):356-375.

De Toni, D. C. \& Hofmann, P. R. P. 1995. Preliminary taxonomic survey of the genus Drosophila (Diptera, Drosophilidae) at Morro da Lagoa da Conceição; Santa Catarina Island; Brazil. Revista Brasileira de Biologia 55(3):347-350.

Dobzhansky, T. \& Pavan, C. 1950. Local and seasonal variations in relative frequencies of species of Drosophila in Brazil. Journal of Animal Ecology 19(1):1-14.

Döge, J. S.; Gottschalk, M. S.; Bizzo, L. E. M.; Oliveira, S. C. F.; Schmitz, H. J.; Valente, V. L. S. \& Hofmann, P. R. P. 2007. The genus Zygothrica Wiedemann 1830 (Diptera, Drosophilidae) in Santa Catarina state, southern Brazil: distribution and ecological notes. Biota Neotropica 7(3):33-36.

Döge, J. S.; GotTschalk, M. S.; De Toni, D. C.; Bizzo, L. E. M.; Oliveira, S. C. F.; Schmitz, H. J.; Valente, V. L. \& Hofmann, P. R. P. 2006. New data on the occurence of the subgenus Drosophila (Drosophila) in Brazil: I. The Drosophila tripunctata species group (Diptera, Drosophilidae). Studia Dipterologica 13(1): $181-187$

Döge, J. S.; Valente, V. L. S. \& Hofmann, P. R. P. 2008. Drosophilids (Diptera) from an Atlantic Forest area in Santa Catarina, southern Brazil. Revista Brasileira de Entomologia 52(4):615-624.

Ferreira, L. B. \& Tidon, R. 2005. Colonizing potential of Drosophilidae (Insecta, Diptera) in environments with different grades of urbanization. Biodiversity and Conservation 14(8): 1809-1821.

Franck, G. \& Valente, V. L. 1985. Study on the flutuation in Drosophila populations of Bento Gonçalves, RS, Brazil. Revista Brasileira de Biologia 45(1/2):133-141.

Goñi, B.; Martinez, M. E. \& Daguer, P. 1997. Studies on two Drosophila (Diptera, Drosophilidae) communities from urban Montevideo, Uruguay. Revista Brasileira de Entomologia 41(1):89-93

Gottschalk, M. S.; De Toni, D. C.; Valente, V. L. \& Hofmann, P. R. P. 2007. Changes in brazilian Drosophilidae (Diptera) assemblages across an urbanisation gradient. Neotropical Entomology 36(6):848-862.

Hammer, Ø.; Harper, D. A. T. \& Ryan, P. D. 2001. PAST: Paleontological statistics software package for education and data analysis. Palaeontologia Electronica 4(1):9.
Hartley, S. \& Shorrocks, B. 2002. A general framework for the aggregation model of coexistence. Journal of Animal Ecology 71(4):651-662.

KANESHIRO, K. Y. 1969. A study of the relationships of Hawaiian Drosophila species based on the external male genitalia. The University of Texas Publication 6918:55-69.

KöPPEN, W. 1948. Climatologia: con un estudio de los climas de la Tierra. Mexico, Fondo de Cultura Economica. 478p.

Krebs, C. J. 1999. Ecological Methodology. Menlo Park, Addison-Wesley Educational. 624p

LEÃo, B. F. D. \& Tidon, R. 2004. Newly invading species exploiting native host-plants: the case of the African Zaprionus indianus (Gupta) in the Brazilian Cerrado (Diptera, Drosophilidae). Annales de la Societe Entomologique de France 40(3/ 4):285-290.

MagurRan, A. E. 2003. Measuring biological diversity. Oxford, Blackwell. 260p

Martins, M. 2001. Drosophilid fruit-fly guilds in forest framents. In: Bierregaard, R. O. JR.; Gascon, C.; Lovejoy, T. E. \& Mesquita, R. ed. Lessons from Amazonia: The ecology and conservation of a fragmented forest. Yale, Yale University. p.175-186.

Mata, R. A.; Roque, F. \& Tidon, R. 2008a. Drosophilids (Insecta, Diptera) of the Paranã Valley: eight new records for the Cerrado biome. Biota Neotropica 8(1):55-60.

Mata, R. A.; McGeoch, M. \& Tidon, R. 2008b. Drosophilid assemblages as a bioindicator system of human disturbance in the Brazilian Savanna. Biodiversity Conservation 17(12):2899-2916

Mateus, R. P.; Buschini, M. L. T. \& Sene, F. M. 2006. The Drosophila community in xerophytic vegetations of the upper Parana-Paraguay river basin. Brazilian Journal of Biology 66(2B):719-729.

McKinney, M. L. 2006. Urbanization as a major cause of biotic homogenization. Biological Conservation 127(3):247-260.

Medeiros, H. F. \& Klaczko, L. B. 2004. How many species of Drosophila (Diptera, Drosophilidae) remain to be described in the forest of São Paulo, Brazil? Species list of three forest remnants. Biota Neotropica 4(1):1-12

Parsons, P. A. 1991. Biodiversity conservation under global climatic change: the insect Drosophila as a biological indicator? Global Ecology and Biogeography Letters 1:77-83.

Pavan, C. 1959. Relações entre populações naturais de Drosophila e o meio ambiente. Boletim da Faculdade de Filosofia, Ciências e Letras, Universidade de São Paulo, Biologia Geral 11(221): 1-81.

PIPKIN, S. B. 1953. Fluctuations in Drosophila populations in a Tropical area. The American Naturalist 87:317-322.

Rooney, T. P.; Olden, J. D.; Leach, M. K. \& Rogers, D. A. 2007. Biotic homogenization and conservation prioritization. Biological Conservation 134(3):447-450.

SaAvedra, C. C. R.; Callegari-Jacoues, S. M.; Napp, M. \& Valente, V. L. 1995. A descriptive and analytical study of four neotropical drosophilid communities. Journal of Zoological Systematics and Evolutionary Research 33:62-74.

Schmitz, H. J.; Valente, V. L. S. \& Hofmann, P. R. P. 2007. Taxonomic survey of Drosophilidae (Diptera) from mangrove forests of Santa Catarina Island, southern Brazil. Neotropical Entomology 36(1):53-64.

Silva, N. M.; Fantinel, C. C.; Valente, V. L. \& Valiati, V. H. 2005a Ecology of colonizing populations of the figfly Zaprionus indianus (Diptera, Drosophilidae) in Porto Alegre, southern Brazil. Iheringia, Série Zoologia, 95(3):233-240.

2005b. Population dynamics of the invasive species Zaprionus indianus (Gupta) (Diptera: Drosophilidae) in communities of drosophilids of Porto Alegre city, southern of Brazil. Neotropical Entomology 34(3):363-374.

Tidon, R. 2006. Relationships between drosophilids (Diptera, Drosophilidae) and the environment in two contrasting tropical vegetations. Biological Journal of the Linnean Society 87(2):233-247.

Tidon, R.; Leite, D. F. \& LeÃo, B. F. D. 2003. Impact of the colonisation of Zaprionus (Diptera, Drosophilidae) in different ecosystems of the Neotropical region: 2 years after the invasion. Biological Conservation 112(3):299-305. 
Tidon, R. \& Sene, F. M. 1988. A trap that retains and keeps Drosophila alive. Drosophila Information Service 67:90.

Tidon-Sklorz, R. \& Sene, F. M. 1992. Vertical and temporal distribution of Drosophila (Diptera, Drosophilidae) species in a wooded area in the state of São Paulo, Brazil. Revista Brasileira de Biologia 52(2):331-317.

Torres, F. R. \& MAdi-RAvazzi, L. 2006. Seasonal variation in natural populations of Drosophila spp. (Diptera) in two woodlands in the state of São Paulo, Brazil. Iheringia, Série Zoologia, 96(4):437-444.
Valiati, V. H.; Sofia, T.; Silva, N. M.; Garcia, A. C. L.; Rohde, C. \& GAiesky, V. L. S. V. 2005. Colonização, competição e coexistência: insetos como modelo de invasões biológicas. Logos 16(1):13-23.

Wheeler, M. R. \& Kambysellis, M. P. 1966. Notes on the Drosophilidae (Diptera) of Samoa. The University of Texas Publication 6615:533-565.

Worm, B. \& DufFy, J. E. 2003. Biodiversity, productivity and stability in real food webs. Trends in Ecology \& Evolution 18(12):628-632.

Recebido em junho de 2008. Aceito em julho de 2009. ISSN 0073-4721

Artigo disponível em: www.scielo.br/isz 